\title{
Corporate Governance and Firm Performance in State-Owned Enterprises (SOEs) in Zambia: A Systematic Review
}

\author{
Bryson Mumba $^{1, *} \&$ Eustarckio Kazonga ${ }^{1}$ \\ ${ }^{1}$ School of Postgraduate Studies, University of Lusaka, P.O Box 36711, Lusaka, Zambia \\ *Corresponding Author: School of Postgraduate Studies, University of Lusaka, P.O Box \\ 36711, Lusaka, Zambia. E-mail: brysonmumba08@gmail.com
}

Received: May 13, $2021 \quad$ Accepted: June 8, $2021 \quad$ Published: September 9, 2021

doi: 10.5296/jegr.v5i1.18641ＵRL: https://doi.org/10.5296/jcgr.v5i1.18641

\begin{abstract}
The research systematically documented and described the corporate governance practices and financial performance in State-Owned Enterprises (SOEs) in Zambia from 2006 to 2017. The research design that was adopted was the descriptive research design to systematically describe the corporate governance practices and financial performance of SOEs in Zambia. The corporate governance attributes for SOEs such as board size, board appointing authorities and board membership have been found to be prescribed by a diversity of Acts of Parliament for different SOEs. This finding suggests that the governance of these entities could be a challenge insofar as the uniformity of the legal framework for the governance of the entities was concerned. In addition to this, board membership which are designated by specific government positions rather than merit based, compromises board effectiveness. The study has further shown that failure to produce and publish, for public scrutiny, audited financial statements on a timely basis leads to lack of transparency and accountability. The financial performance has been found to have been poor as the SOEs on average produced negative returns on total assets and the SOEs were highly geared based on operating gearing and financing gearing. Lastly, financial performance of SOEs and the corporate governance practices differed significantly across different industries under which the SOEs operated.
\end{abstract}

Keywords: corporate governance, firm financial performance, State-Owned Enterprises, systematic review, Zambia. 


\section{Introduction}

The research sought to document and describe the financial performance and corporate governance practices in State-Owned Enterprises (SOEs) in Zambia from 2006 to 2017. The financial performance of SOEs from 2006 to 2017 was analyzed by use of key financial ratios measuring profitability, operating gearing, short term liquidity and financial gearing. Corporate governance practices were described thematically. The themes comprised legal status, board appointing authority, board appointing process, board size, board tenure and eligibility for re-appointment, type of board, board composition, board nominations and ex-officio members of the board. This was a country specific study.

\section{Literature Review}

There are many definitions of corporate governance. One such definition is that by Cornelius (2005:1) who defined corporate governance as "the stewardship responsibility of corporate directors to provide oversight for the goals and strategies of a company and to foster their implementation". Specific to emerging countries good corporate governance has been found to affect economic stability and future growth prospects (Abdo \& Fisher, 2007, Khana \& Zyla, 2016). A key aspect of emerging market economies is the role of State-Owned Enterprises (SOEs). SOEs play an important role in many economies in Africa and across the world. According to the World Bank (2006:3), "SOEs account for close to $20 \%$ of the total non-agricultural economic activities in an average low-income developing country". Further, Armitage (2014:26) indicated that:

204 of the world's 2,000 largest publicly listed firms were identified as parastatals in 2010-2011. The combined sales of these parastatals amounted to US \$3.6 Trillion, representing more than $10 \%$ of the aggregate sales of the 2,000 world's largest companies. The value of sales of these parastatals is tantamount to almost $6 \%$ of the world GDP.

From the above, it is clear that SOEs contribute to the much needed resources to nations. For example, they provide essential services in areas including water, sanitation, electricity, communication and transport and in most emerging economics and Southern Africa is almost totally reliant on SOEs (Armitage, 2014).

Good corporate governance is a key factor in ensuring high returns on investments in SOEs and national levels, generally. It is to this effect that poor corporate governance results in poor management of investments. To support this, Chanda, Burton and Dunne (2015) observed that the management of national economies was affected by poor corporate governance. Armitage (2014) once suggested that the governance of SOEs in Zambia remains to be problematic, mainly due to corporate governance challenges. Noting the challenge of corporate governance, Perelman and Pestieau (2019) have suggested that there is need for empirical research to inform the improvements of both corporate governance and performance of SOEs. Thus, Okeahalam (2004) has identified the need for researching the corporate governance policy development in Africa. In the case of Zambia, Chanda et al. 
(2015:2) have found that, "understanding of corporate governance is at an embryonic stage in Zambia". Similarly, Chulu (2006) found that there was scarce empirical literature on corporate governance practices and the roles and composition of the board of directors in Zambia.

On the $30^{\text {th }}$ of November 2017, the Report of the Auditor General of Zambia on Accounts of SOEs for the financial years ended $31^{\text {st }}$ December 2013 to 2016 was released. The Auditor General's report revealed poor financial performance by SOEs and attributed it to, among others, continued weak corporate governance (Auditor General, 2018: ii). While this has been stated, the report has pointed out domains in corporate governance that could be isolated for mitigation. The main areas include:

1) Failure to constitute board of directors;

2) Failure to Convene Annual General Meetings;

3) Failure to Prepare Annual Reports;

4) Expiry of the Tenure of the Board;

5) Frequency of Board Dissolutions and Re-appointments and

6) Excessive Number of Board Meetings.

The consequence associated with such a state of poor corporate governance in SOEs is that they will continue to be a drain on the meagre national resources as they are not giving back to the public as expected. Accordingly, this study was focused on discovering the financial performance and corporate governance practices in SOEs in Zambia covering the period from 2006 to 2017 in order to narrow the knowledge gap on the empirical literature on corporate governance practices and the roles and composition of the board of directors in Zambia. The sources of knowledge in describing the corporate governance practices and firm financial performance in SOEs from 2006 to 2017 comprised documentary sources of knowledge such as existing annual reports, Auditor General's reports, published research papers, SOEs' Acts enacted for the establishments of the SOEs and Articles of Association. The study outcomes may be useful to policy makers, investors, board appointment authorities, company managers and the academic community as it would deliver systematically derived knowledge on the financial performance and corporate governance practices in SOEs in Zambia.

\section{Methodology}

The research design that was followed was a systematic survey of the literature following the procedures proposed by Tranfield, Denyer and Smart (2003). The systematic review steps and what was done is described next.

Step 1: Review question

The research question that was investigated was "What were the financial performance and corporate governance practices in SOEs in Zambia from 2006 to 2017?" 


\section{Macrothink}

Step 2: Eligibility criteria for studies to be included

The eligibility criteria for inclusion of literature in the systematic review were key words which were the actual names of the SOES in Zambia, Annual Reports, Parastatals, Firm financial performance and corporate governance.

Step 3: Comprehensive search for studies that meet the eligibility criteria

Documentary sources of knowledge that were used included existing annual reports, Auditor General's reports, published research papers in electronic databases, SOEs' Acts enacted for the establishments of the SOEs and Articles of Association.

Step 4: Identifying and selecting relevant studies

The documentary sources were considered relevant if they were Annual Reports of Zambian SOEs, was on Parastatals in Zambia, was concerned with SOEs firm financial performance and corporate governance and related to the period 2006 to 2017.

Step 5: Data extraction

The data that was extracted was recorded using the template in Table 1.

Table 1. Data Collection Template

\begin{tabular}{ll}
\hline Factor & Data \\
\hline Entity & Company Name \\
Legislation & Type of entity \\
Corporate Governance Attributes & Enabling Acts \\
& Board appointing Authority \\
& Board appointment process \\
& Board composition \\
& Ex Officio board members \\
& Board tenure \\
& Board size \\
& Board diversity - gender representation on the board \\
& Transparency - publication of annual reports and audited \\
& financial statements \\
& Board member skills requirements \\
& Board chairmanship \\
& Non-Executive Directors of the Board \\
& Executive Directors of the Board \\
& Shareholdings \\
Total Assets \\
Profit before Tax (PBT) \\
Return on Total Assets (ROTA) - calculated as PBT/Total \\
Assets \\
\hline
\end{tabular}


Step 6: Synthesis of results

The extracted data was synthesized using a descriptive approach in which the corporate governance practices and financial performance of SOEs in Zambia were analyzed. The qualitative form of data analysis that was used was a combination of narrative analysis and thematic analysis. The qualitative analysis was conducted based on a deductive thematic analysis approach. The identified themes included were as per Table 1. During the synthesis of the firm financial performance data and corporate governance attributes data, any missing data were eliminated from the trend and descriptive statistics. The concerned descriptive statistics included the arithmetic mean, minimum and maximum values of the extracted data. The One-Way ANOVA technique was also employed to determine whether industry affected the firm financial performance and corporate governance practices across firms.

\section{Findings}

\subsection{The Birth of SOEs in Zambia - a Timeline}

Historically, SOEs in Zambia have played an important and growing role through their contribution to Gross Domestic Product (GDP). For instance, Fundanga and Mwaba (2005) have noted that from the mid-1960 to the 1980s, SOEs' contribution to the Zambian economy rose from $14 \%$ to more than $80 \%$. In terms of the asset value of these SOEs, the IDC (2015) estimated the net asset portfolio owned by the SOEs to be in the range of US\$2 billion which assets were held in various countries including Tanzania and the United Kingdom.

The key dates and events in the history of SOEs in Zambia is shown in Figure 1.

\subsubsection{Pre-independence}

Significant state ownership of companies in Zambia commenced in 1964 with the incorporation of the Industrial Development Corporation (INDECO) which was wholly owned by the Government (Fundanga \& Mwaba, 2005). Prior to independence, the state owned some enterprises such as railways and utility companies and the private sector was well established in a market-oriented economy.

\subsubsection{The Mulungushi and Matero Reforms}

The Mulungushi Reforms of 1968 ushered in government ownership of over 28 companies through the nationalization of private firms (Fundanga \& Mwaba, 2005). These nationalized firms were involved in diverse commercial activities across many sectors of the economy including retail shops, agriculture, construction, transportation, tourism, brewing and quarry business but excluding the copper mines (ibid). The Zambia Industrial and Mining Corporation (ZIMCO), was then established in 1970 as the holding company of the many SOEs (Turok, 1981). The management of the state-owned enterprises was through sector ministries even though ownership of the companies was by ZIMCO. However, the mining companies were nationalized in 1969 during the Matero Reforms which saw the creation of Roan Copper Mines (RCM) and Nchanga Consolidated Copper Mines (NCCM) (Turok, 
1981).

1964

-INDECO formed as an SOE

-Mulungushi Reforms

1968 -Natianalisation of 28 private enterprises except the mines

-Matero Reforms

-Nationalisation of the mines and creation of NCCM (Nchanga Consolidated Copper Mines and RCM (Roan Copper Mines)

-Zambia Industrial Mining Corporation (ZIMCO) formation

1979 -Delinked the state owned enterprises from line ministries and MINDECO formed to manage the mines

-Zambia Consolidated Copper Mines (ZCCM) formed which brought NCCM and RCM under ZCCM

-Industrial Development Company (IDC) incorporated

2014

Figure 1. Key Dates and Events in the History of SOEs in Zambia - a Time Line

\subsubsection{The 1979 Reforms}

Following on the first two reforms, another key reform was conducted in 1979 when the management of state owned enterprises was brought under the control of directorates at the Zambia Industrial Corporation (ZIMCO) as opposed to being under sector ministries. The mining sector companies were however, put under the newly formed parastatal called Mining Industrial Company (MINDECO).

\subsubsection{The Formation of Zambia Consolidated Copper Mines (ZCCM) - 1982}

In 1982, Zambia Consolidated Copper Mines (ZCCM) was formed. The main responsibility of this consortium was investment in SOEs involved in mining. This meant that NCCM and RCM were now under ZCCM.

\subsubsection{Industrial Development Corporation (IDC) formed - 2014}

The Industrial Development Corporation of Zambia was incorporated in early 2014 (IDC, 2015). It is an investment company for SOEs in Zambia and it is owned by the Zambian government.

\subsection{Poor Financial Performance by SOEs in Zambia}

\subsubsection{Background}

The financial performance of many SOEs in Zambia has largely been poor. Therefore, these SOEs have received negative perception from the public regardless of their potential to provide benefits to the public (Armitage, 2014). Among the key reasons for the poor performance of SOEs include, weak governance and poor management (Armitage, 2014). Further, Fundanga and Mwaba (2005) identified factors that led to poor financial performance of SOEs as being inappropriate technology, inexperienced management and 
misapplication of resources by politically connected managers, among others. As a consequence of poor financial performance, the government has had to provide subsidies to SOEs in Zambia in order to ensure that they remain afloat. These resources are often diverted from other pressing national needs such as health and education. Therefore, the provision of subsidies to SOEs implies consumption instead of contribution to the GDP of Zambia. The Auditor General's report on parastatal bodies and other statutory institutions for the 2017 financial year has shown that the audited institutions could not remit K1.7 billion of statutory benefits. This meant that Government and Zambia "were deprived of revenue in non-remittances to the National Pension Scheme Authority and contributions to the Local Government Superannuation Fund" (Auditor General, 2017:5).

\subsubsection{Financial Performance Analysis of SOEs}

In addressing the above question, this section sought to discover the financial performance of SOEs from 2006 to 2017 by use of financial ratios. The key financial ratios investigated included ratios measuring profitability, financial gearing and liquidity of SOEs. In measuring the profitability ROTA and the ratio of fixed operating costs to revenue were employed, the ratio of total liabilities to total equity was employed to measure long term liquidity or Financial Gearing and the Current Ratio or the ratio of current assets to current liabilities was employed to measure short-term liquidity. Table 2 provides a description of the variables.

Table 2. Description of Variables Used to Measure Financial Performance of SOEs

\begin{tabular}{lll}
\hline \multicolumn{1}{c}{ Variable } & \multicolumn{1}{c}{ Measure } & \multicolumn{1}{c}{ Definition } \\
\hline Profitability & Return on Total Assets & Total profit before tax/Total Assets \\
Profitability & Fixed cost ratio & Fixed Operating Costs/Revenue \\
Long Term liquidity Risk & Financial Gearing & Total Liabilities/Total Equity \\
Short-term Liquidity & Current Ratio & Total Current Assets/Total Current Liabilities \\
\hline
\end{tabular}

Table 3 shows the descriptive statistics of the financial data.

Table 3. Descriptive Statistics for SOEs Financial Performance 2006- 2017

\begin{tabular}{|c|c|c|c|c|}
\hline & $\begin{array}{l}\text { Operating } \\
\text { Risk(Operating } \\
\text { Costs/Revenue) }\end{array}$ & $\begin{array}{l}\text { Financial } \\
\text { Risk(PBIT/Interest } \\
\text { costs) }\end{array}$ & $\begin{array}{l}\text { Financial } \\
\text { Gearing(Total } \\
\text { Liabilities/Total } \\
\text { Equity) }\end{array}$ & $\begin{array}{l}\text { Short Term } \\
\text { Liquidity(Current } \\
\text { Assets/Current } \\
\text { Liabilities) }\end{array}$ \\
\hline Mean & 1.0889 & 4.0382 & $(4.2240)$ & 1.8821 \\
\hline Minimum & 0.0218 & (11.3459) & $(702.5780)$ & 0.0357 \\
\hline Maximum & 28.3561 & 32.9051 & 138.3315 & 70.9829 \\
\hline Standard Dev & 1.9970 & 11.7402 & 55.2768 & 6.1202 \\
\hline Skewness & 12.8587 & 1.0832 & (10.9477) & 8.8345 \\
\hline Kurtosis & 176.0408 & 0.8577 & 134.8244 & 91.3420 \\
\hline Median & 0.8902 & $(0.0017)$ & 0.4007 & 0.5384 \\
\hline Mode & 1.0813 & N/A & 5.4181 & 29.4323 \\
\hline
\end{tabular}


4.2.3 Profitability Analysis Measured by ROTA

There was an improvement in the firm financial performance as measured by the mean of the ROTA over the period as shown in Figure 2. Over the period the overall mean was negative $8.01 \%$ meaning that the SOEs made losses over the period.

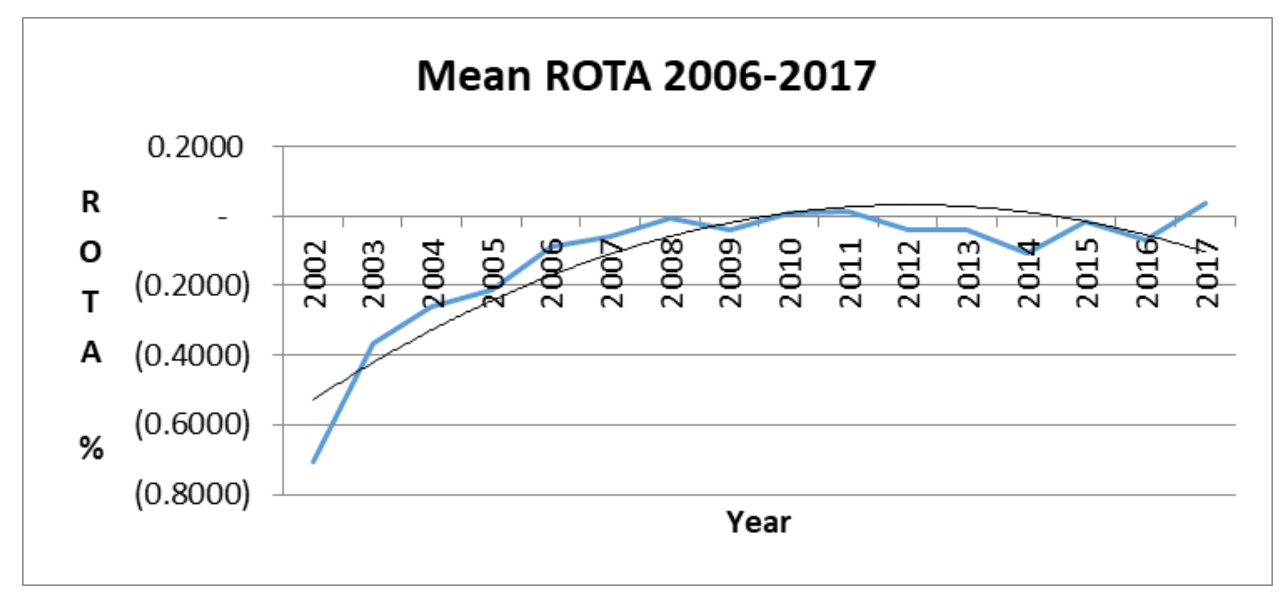

Figure 2. ROTA Trend Analysis

\subsubsection{Fixed Cost to Revenue Ratio}

Figure 3 shows that the overall fixed cost to revenue ratio recorded over the period was a mean of $108.89 \%$ meaning that the fixed costs were more than the revenue. In 2014 the spike in the ratio was due to IDC that recorded a ratio of $2,835 \%$ as 2014 was the first year of operation and there was little revenue as compared to fixed costs.

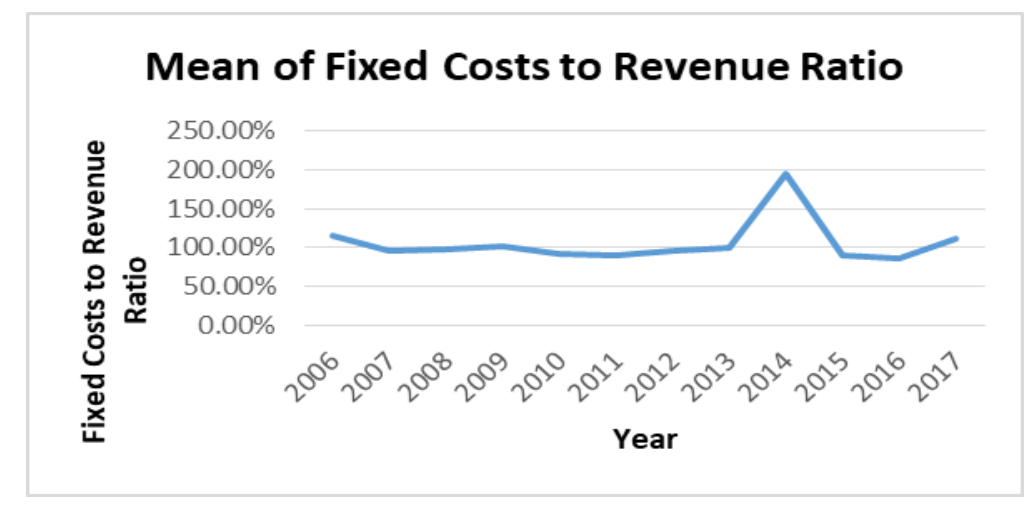

Figure 3. Fixed Cost to Revenue Ratio Trends

\subsubsection{Short-Term Liquidity}

The Current ratio measured by the ratio Total Current Assets divided by Total Current 


\section{Macrothink}

Journal of Corporate Governance Research

ISSN 1948-4658

2021, Vol. 5, No. 1

Liabilities was employed to discover the short-term liquidity of the SOEs. Table 5 shows that overall, the mean Current Ratio was 1.88 and the trend was generally upwards. The spike in 2014 was due to the IDC that had very low current liabilities of K19,740 as compared to the current assets of K6.5million.

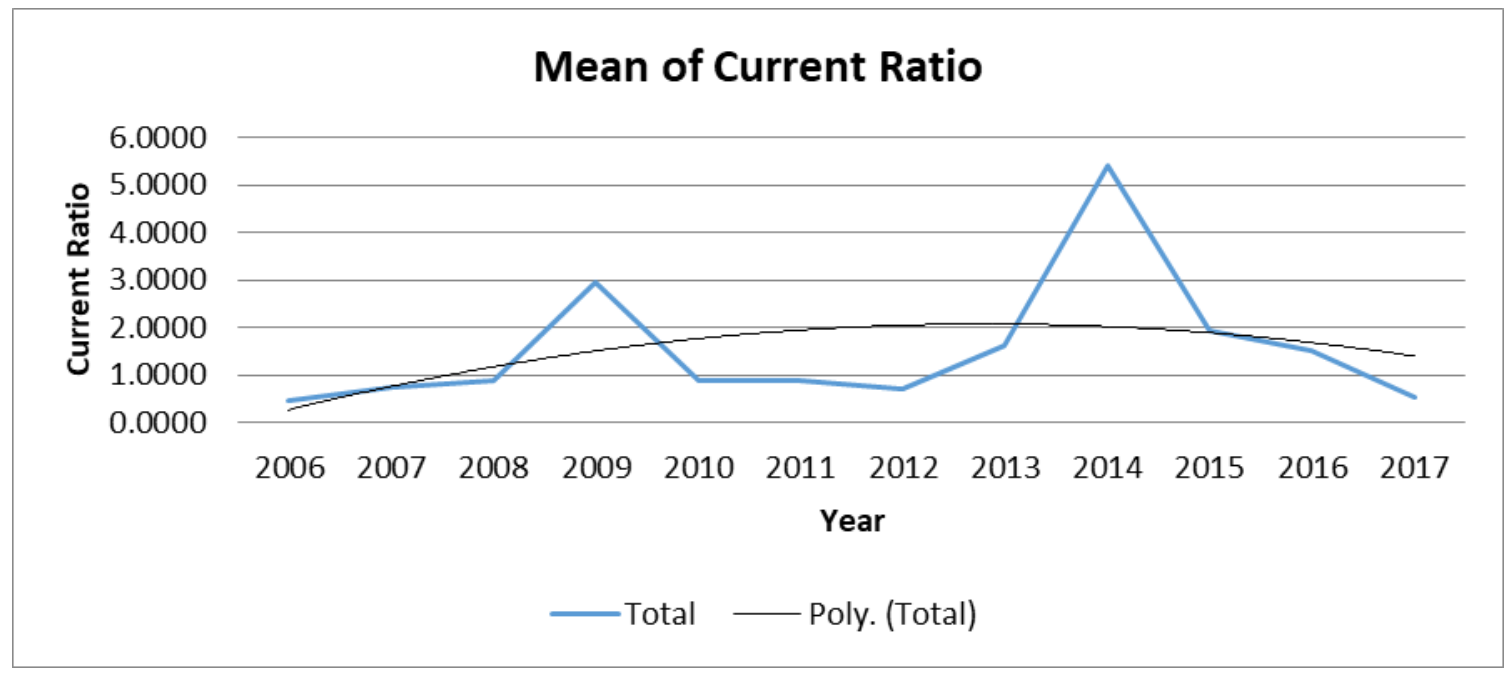

Figure 4. Short Term Liquidity Trends

\subsubsection{Financial Gearing}

The financial gearing ratio measured by the Total Liabilities/Total Equity was employed to discover the long term liquidity of the SOEs. Figure 5 shows that overall, the mean ratio was negative 4.22 and the trend was generally flat over the period except for a spike in 2007 . The spike in 2007 was due to the Zamtel and Natsave performance of negative 271.48 and negative 702.58 , respectively.

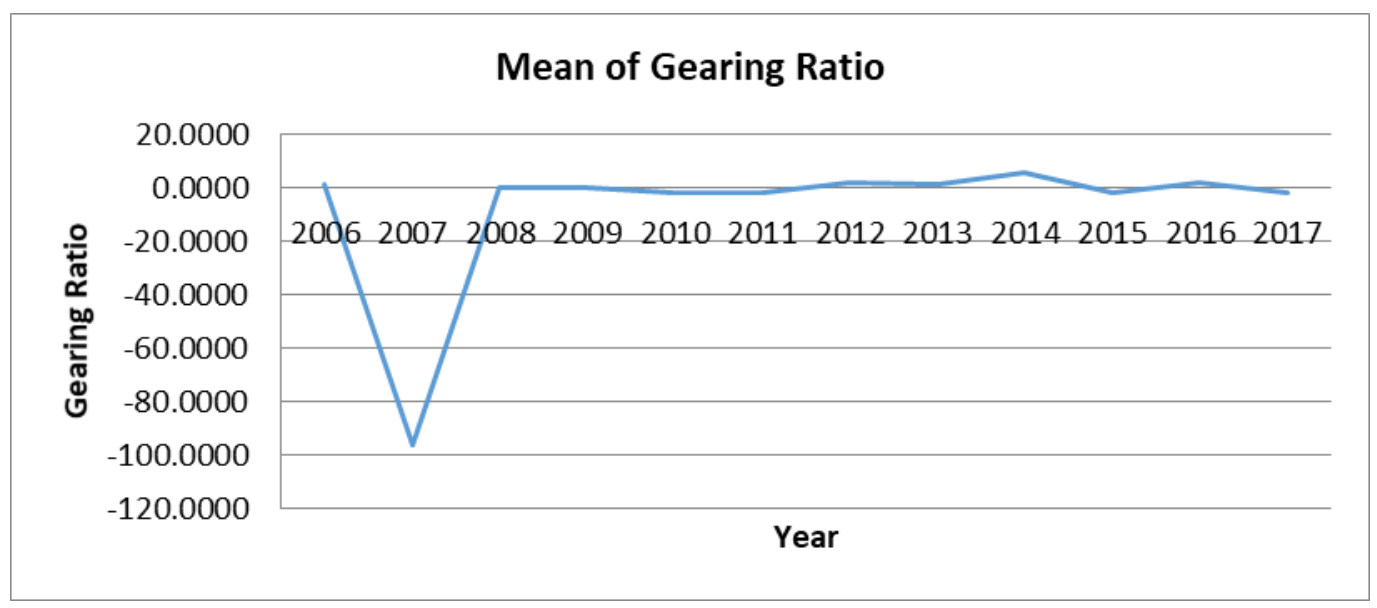

Figure 5. Financial Gearing Trends 


\section{Macrothink}

\subsubsection{Financial Gearing - Negative Gearing}

The financial gearing ratio was further analyzed separately into those showing negative ratios and those showing a positive ratio. The overall mean over the period was -3.89 and the trend was an upward trend for negative ratio trend as per Figure 6.

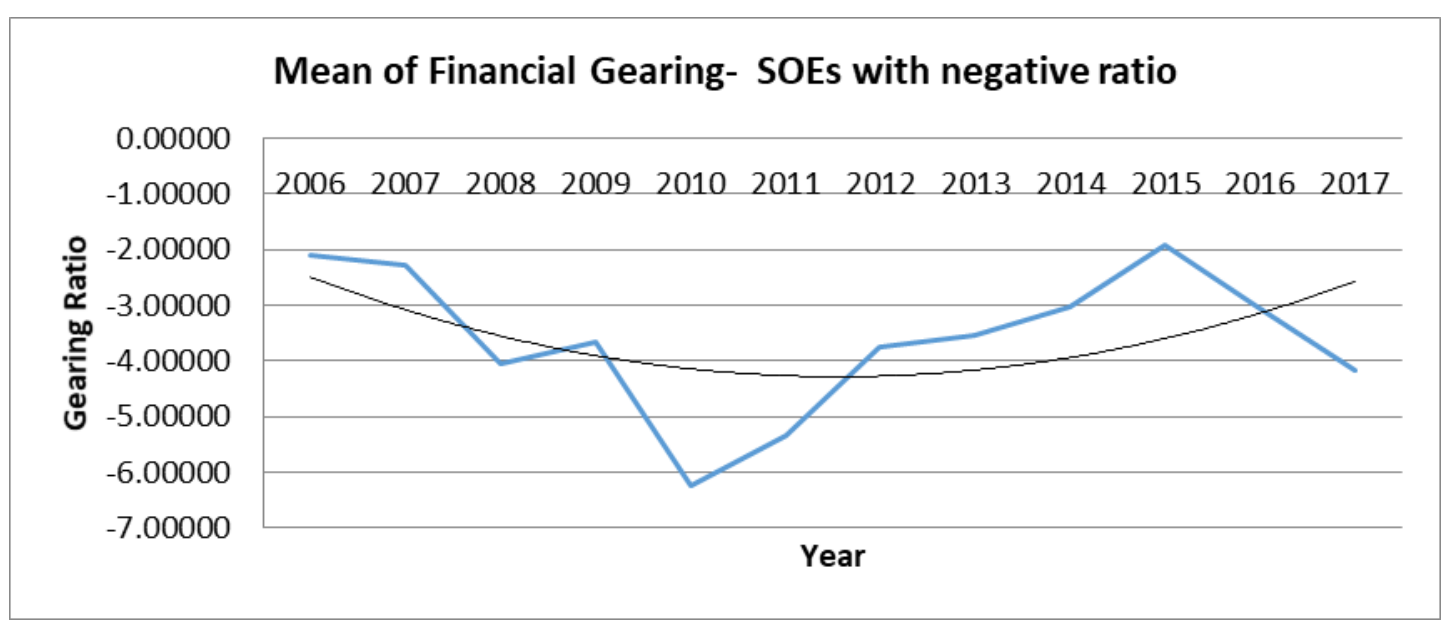

Figure 6. Financial Gearing ratio - Negative Ratios Trend

\subsubsection{Financial gearing - Positive Gearing trend}

The overall mean over the period for companies with positive gearing was 2.49 and the trend was a downward trend for positive ratio trend as per Figure 7.

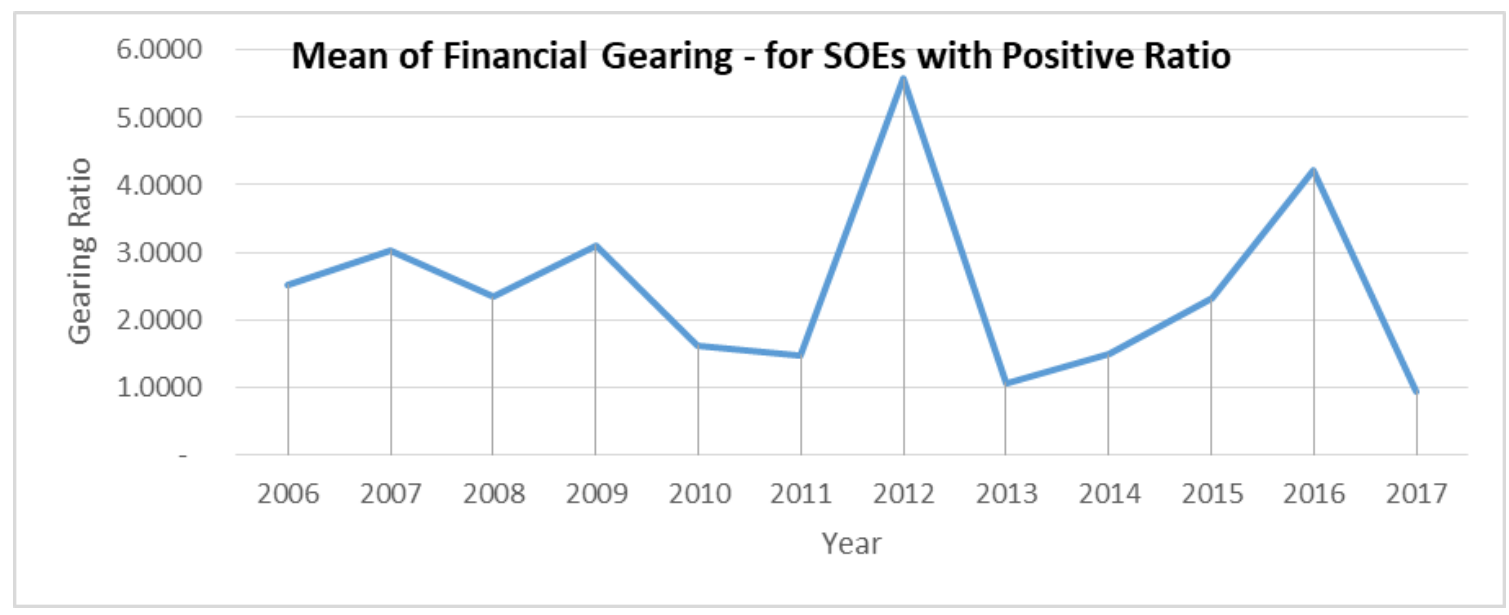

Figure 7. Financial gearing - Positive Gearing Trend 
4.3 Corporate Governance Practices in SOEs from 2006 to 2017

The corporate governance practices were described thematically. The themes comprised legal status, board appointing Authority, board appointing process, board size, board tenure and eligibility for re-appointment, type of board, board composition, board nominations and ex-officio members of the board, CEO duality and timely production of annual audited financial statements.

\subsubsection{Legal Status}

Figure 8 showed that that $42 \%$ (37 out of 86 ) institutions were incorporated under the Companies Act Cap 388 while 58\% (49 out of 86) institutions were incorporated under various Acts of Parliament other than the Companies Act. In total there are over 37 different enabling Acts under which the SOEs and statutory bodies are founded.

From a corporate governance point of view, it has been established that the Acts of Parliament prescribed the corporate governance attributes for SOEs such as board type, board appointing authorities, appointments of Chairpersons, board size, board tenure and board membership. This fact meant that the governance of these entities could be a challenge insofar as the uniformity of the legal framework for the governance of the entities was concerned. As was pointed out by Cornelius (2005), corporate governance was affected by, among other factors, the legal framework in a particular country.

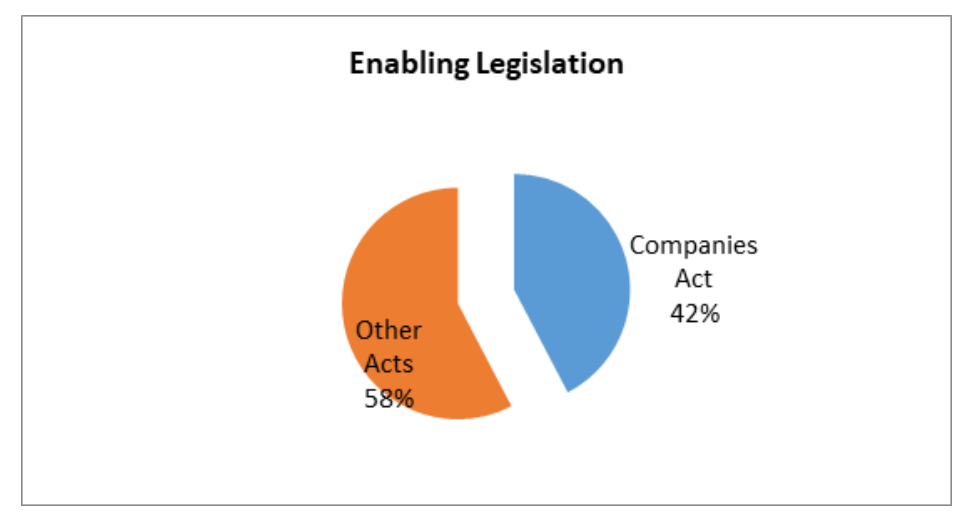

Figure 8. Enabling Legislation

\subsubsection{Type of Boards}

The findings show that one company, TAZARA, had a two-tier board comprising a Council of Ministers which superintended over a second board of directors. All the other institutions comprised a single tier board.

\subsubsection{Board Appointing Authority}

The boards were appointed by the Minister in almost all institutions. There were a number of 


\section{Macrothink}

Journal of Corporate Governance Research

ISSN 1948-4658

2021, Vol. 5, No. 1

boards that were appointed by the Republican President which included Zambia Public Procurement Authority (ZPPA), Citizen Economic Empowerment Commission (CEEC), Public Service Pension Fund (PSPF) and the Industrial Development Corporation (IDC). The Republican President also chaired the IDC Board of Directors. In the case of the Development Bank of Zambia (DBZ), the Minister, representing the Government holding Class A shares, appointed four of the members whilst five members were appointed by the shareholders of Class B shares. The board of directors for Mukuba Motel Limited, the Chairperson of the Show Society of Zambia appointed the board. Boards of subsidiary companies of SOEs were appointed by the holding companies which included the Zamnet board that was appointed by the University of Zambia being the holding institution, Ndola Lime Limited board was appointed by ZCCM-IH, and IDC appointed the boards for ZSIC Limited and Medical Stores Limited.

\subsubsection{Appointments of Chairpersons and Vice Chairpersons}

The appointments of Chairpersons were found to be as per Table 4. In most cases, the appointing Authority also appointed the chairpersons of the Board.

Table 4. Appointing Authority for Chairpersons

\begin{tabular}{lll}
\hline Appointing Authority & Number & Percentage (\%) \\
\hline Appointed by the Minister & 33 & 80 \\
Appointed by the President & 2 & 5 \\
Appointed from among members & 4 & 10 \\
Designated Chairperson & 2 & 5 \\
Total & 41 & 100 \\
\hline
\end{tabular}

\subsubsection{Board Size}

The overall size of the board ranged from a minimum of five members to a maximum of 18 members with a mean of 10 members. For companies registered under the Companies Act, the board size ranged from a minimum of six members to a maximum of 11 members with a mean of 9 members. For companies registered under other legislation other than companies Act, the size of the board ranged from a minimum of five members to a maximum of 18 members with a mean of 11 members. Table 5 provides the summary statistics on Board size. 
Table 5. Board Size

\begin{tabular}{llc}
\hline & Summary measure & Board Size \\
\hline Overall & & 5 \\
& Minimum & 10 \\
& Average & 18 \\
\multirow{3}{*}{ Limited companies } & Maximum & 6 \\
& Minimum & 9 \\
& Average & 11 \\
\multirow{3}{*}{ Others } & Maximum & \\
& & 5 \\
& Minimum & 11 \\
& Average & 18 \\
\hline
\end{tabular}

\subsubsection{Board Tenure}

The overall tenure of a board ranged from a minimum of two years to a maximum of four years with an average of three years. For companies incorporated under the Companies Act, the tenure of the board ranged from a minimum of three years to a maximum of four years with an average of three years. For companies registered under other legislation other than companies Act, the tenure of the board ranged from a minimum of two years to a maximum of four years with an average of three years. Table 6 provides the summary statistics on Board tenure:

Table 6. Board Tenure

\begin{tabular}{llc}
\hline & Summary measure & Board Tenure - Years \\
\hline Overall & Minimum & 2 \\
& Average & 3 \\
& Maximum & 4 \\
\multirow{3}{*}{ Limited companies } & Minimum & 3 \\
& Average & 3 \\
\multirow{3}{*}{ Others } & Maximum & 4 \\
& Minimum & 2 \\
& Average & 3 \\
& Maximum & 4 \\
\hline
\end{tabular}

\subsubsection{Board Composition}

The compositions of the Boards of Directors is summarized in Table 7. 


\section{Macrothink}

Journal of Corporate Governance Research

ISSN 1948-4658

2021, Vol. 5, No. 1

In most of the statutory bodies the board positions are designated for specific office holders from the government and/or representatives from specific institutions.

Table 7. Board Composition

\begin{tabular}{lc}
\hline Board composition by: & Total \\
\hline Designated representatives & 48 \\
By Direct Appointment & 24 \\
Mixed (some by designation and others appointed) & 12 \\
\hline
\end{tabular}

The IDC board on $29^{\text {th }}$ December 2015 passed a resolution pertaining to the number of Board members on IDC subsidiaries. It was resolved that the boards shall comprise the Permanent Secretary or a representative of the Ministry responsible for the Sector Policy, and a maximum of five (5) members from the private sector. The Managing Director was also a board member (Auditor General, 2015).

\subsubsection{Non-Executive Directors}

On average, it was found that Non-Executive Directors comprised $97 \%$ of the board composition. The Chief Executive Officers, who are part of management, were also members of the board.

\subsubsection{Gender diversity on Boards}

The findings show that only one SOE namely, Rural Electrification Authority's board composition has a quota of two positions reserved for female board members as provided for under the Rural Electrification Authority Act No. 20 of 2003.

Transparency and accountability - Production of annual audited financial statements

Based on the auditor general's reports from 2012 to 2016, it was found that a number of statutory bodies (refer to Figure 9) and SOEs had not produced audited financial statements annually as was required by the various enabling legislation under which the SOEs operated and contrary to good corporate governance. 


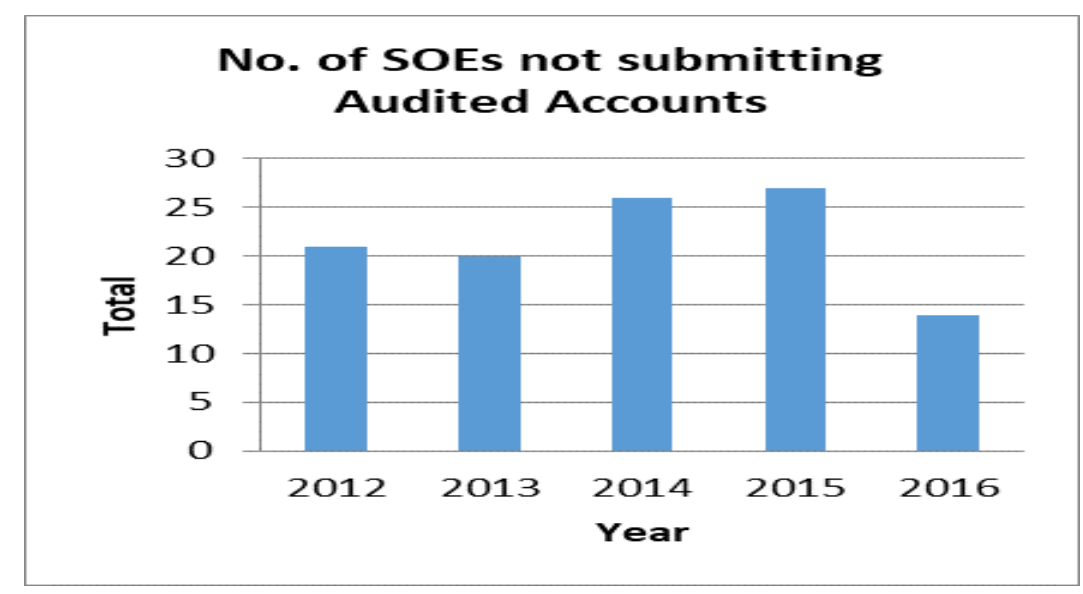

Figure 9. Number of Statutory Bodies and SOEs not Submitting Audited Financial Statements

\subsection{Financial Performance and Corporate Governance Practices Industry Comparisons}

The financial performance measures and the corporate governance practices were compared across industries using One-Way ANOVA. The null hypotheses tested were that there was no significant difference in the financial performance of SOEs across different industries and also that there was no significant difference in the corporate governance practices in SOEs across different industries. As shown in Table 8 and Appendices 1 to 7, the findings were that the null hypotheses were rejected as the p-values were below 0.05 meaning that the financial performance of SOEs differed significantly across industries and also that the corporate governance practices differed significantly across different industries.

Table 8. Summary of One-Way ANOVA for Firm Financial Performance and Corporate Governance Practices Across Industries

\begin{tabular}{lc}
\hline Variable & p-value \\
\hline Operating gearing & 0.0000 \\
Current Ratio & 0.0000 \\
Financial Gearing & 0.0008 \\
Return on Total Assets(ROTA) & 0.0000 \\
Board Size & 0.0000 \\
Proportion of Non-executive Directors on the Board of Directors & 0.0000 \\
Proportion of Female Board members on the Board of Directors & 0.0097 \\
\hline
\end{tabular}

\section{Conclusion}

The study has documented the corporate governance practices and financial performance in SOEs in Zambia during the period 2006-2017. The corporate governance attributes for SOEs 
such as board size, board appointing authorities and board membership have been found to be prescribed by a diversity of Acts of Parliament for different SOEs. This finding suggests that the governance of these entities could be a challenge insofar as the uniformity of the legal framework for the governance of the entities was concerned. In addition to this, board membership which are designated by specific government positions rather than merit based, compromises board effectiveness. The study has further shown that failure to produce and publish, for public scrutiny, audited financial statements on a timely basis leads to lack of transparency and accountability. The financial performance has been found to have been poor as the SOEs on average produced negative returns on total assets and the SOEs were highly geared based on operating gearing and financing gearing. Lastly, financial performance of SOEs and the corporate governance practices differed significantly across different industries under which the SOEs operated. Further research could be conducted to compare the financial performance and corporate governance practices of SOEs in Zambia with those of listed firms in Zambia.

\section{References}

Abdo, A. and Fisher, G. (2007). The impact of reported corporate governance disclosure on the financial performance of companies listed on the JSE. Investment Analysis Journal. $\begin{array}{llll}\text { Retrieved } & 18 & \text { December, } & 2018\end{array}$ http://www.tandfonline.com/doi/abs/10.1080/10293523.2007.11082492. 8

Armitage, A. (2014). Parastatal Policy Analysis, PMRC, Lusaka.

Auditor, G. (2008). Report of the Auditor General for 2008 on the accounts of parastatal bodies and other statutory Institutions, Lusaka.

Auditor, G. (2009). Report of the Auditor General for 2009 on the accounts of parastatal bodies and other statutory Institutions, Lusaka.

Auditor, G. (2010). Report of the Auditor General for 2010 on the accounts of parastatal bodies and other statutory Institutions, Lusaka.

Auditor, G. (2011). Report of the Auditor General for 2011 on the accounts of parastatal bodies and other statutory Institutions, Lusaka.

Auditor, G. (2012). Report of the Auditor General for 2012 on the accounts of parastatal bodies and other statutory Institutions, Lusaka.

Auditor, G. (2013). Report of the Auditor General for 2013 on the accounts of parastatal bodies and other statutory Institutions, Lusaka.

Auditor, G. (2014). Report of the Auditor General for 2014 on the accounts of parastatal bodies and other statutory Institutions, Lusaka.

Auditor, G. (2015). Report of the Auditor General for 2015 on the accounts of parastatal bodies and other statutory Institutions, Lusaka. 
Auditor, G. (2016). Report of the Auditor General for 2016 on the accounts of parastatal bodies and other statutory Institutions, Lusaka.

Auditor, G. (2017). Report of the Auditor General for 2017 on the accounts of parastatal bodies and other statutory Institutions, Lusaka.

Auditor, G. (2018). Report of the Auditor General for 2018 on the accounts of parastatal bodies and other statutory Institutions, Lusaka

Chanda, S., Burton, B., \& Dunne, T. (2015). The Nature and Potential of corporate governance in developing countries: Zambian perceptions. Accounting, Auditing and Accountability Journal, 30(6), 1257-1287. https://doi.org/10.1108/AAAJ-08-2015-2208

Chulu, M. J. (2006). Regulating Board-Level Corporate Governance in Public Companies in Zambia: A Multi-method study. Retrieved 24 December, 2020 from https://ethos.bl.uk/OrderDetails.do?uin=uk.bl.ethos.436303

Cornelius, P. (2005). Good corporate practices in poor corporate governance systems: Some evidence from the Global Competitiveness Report. Corporate Governance, 5(3), 12-23. https://doi.org/10.1108/14720700510604661

Fundanga, C., \& Mwaba, A. (2005). Privatization of Public Enterprises in Zambia: An Evaluation of the Policies, Procedures and Experiences, AfDB. Economics Research paper, (35). $\quad$ Retrieved $28 \quad$ May, 2019 from https://www.afdb.org/fileadmin/uploads/afdb/Documents/Publications/00157604-FR-ER P-35.PDF

Industrial Development Corporation (IDC). (2015). About IDC. Retrieved 07 January, 2017 from http://www.idc.co.zm/about-idc.

Khana, V., \& Zyla, R. (2016). Corportate Governance Matters to Investors in Emerging Market Companies, IFC, NW Washington, DC. https://doi.org/10.1596/26508

Okeahalam, C. C. (2004). Corporate governance and disclosure in Africa: Issues and challenges. Journal of Financial Regulation and Compliance, 12(4), 359-370, https://doi.org/10.1108/13581980410810902

Perelman, S., \& Pestieau, P. (2019). The performance of public enterprises, No 2019003, CORE Discussion Papers from Université catholique de Louvain, Center for Operations Research and Econometrics (CORE).

Tranfield, D., Denyer, D., \& Smart, P. (2003). Towards a methodology for developing evidence-informed management knowledge by means of systematic review. $\mathrm{Br} \mathrm{J}$ Management 14(3), 207-222. https://doi.org/10.1111/1467-8551.00375

Turok, B. (1981). Control of the Parastatal Sector in Zambia. The Journal of Modern African Studies, 19(3), 421-445. Retrieved from https://www.jstor.org/stable/160753. Accessed on 22nd September 2018. https://doi.org/10.1017/S0022278X00014956

World Bank. (2006). Corporate Governance Country Assessment: Zambia. Washington, DC. 
(C) World

Bank.

Retrieved

from

https://openknowledge.worldbank.org/handle/10986/8198 License: CC BY 3.0.

Appendices

Appendix 1. One-Way ANOVA for Operating Gearing

Table 1. Analysis of Variance

\begin{tabular}{llllll}
\hline Source & ss & df & MS & F & Prob > F \\
\hline Between groups & 244.548957 & 17 & 14.3852328 & 4.76 & 0.0000 \\
within groups & 553.073355 & 183 & 3.02225877 & & \\
Total & 797.622312 & 200 & 3.98811156 & & \\
\hline
\end{tabular}

\section{Appendix 2. One-Way ANOVA for Short term Liquidity}

Table 2. Analysis of Variance

\begin{tabular}{llllll}
\hline Source & ss & df & MS & F & Prob $>$ F \\
\hline Between groups & 2072.52277 & 16 & 129.532673 & 4.49 & 0.0000 \\
within groups & 4932.00198 & 171 & 28.8421168 & & \\
Total & 7004.52475 & 187 & 37.4573516 & & \\
\hline
\end{tabular}

Bartlett's test for equal variances: $\operatorname{chi} 2(16)=553.1473$ Prob $>$ chi $2=0.000$

\section{Appendix 3. One-Way ANOVA for Financial Gearing}

Table 3. Analysis of Variance

\begin{tabular}{llllll}
\hline Source & ss & df & MS & F & Prob $>$ F \\
\hline Between groups & 119967.145 & 17 & 7056.89089 & 2.64 & 0.0008 \\
within groups & 475859.94 & 178 & 2673.37045 & & \\
Total & 595827.085 & 195 & 3055.52351 & & \\
\hline
\end{tabular}

\section{Appendix 4. One-Way ANOVA for Return on Total Assets}

Table 4. Analysis of Variance

\begin{tabular}{llllll}
\hline Source & ss & df & MS & F & Prob $>$ F \\
\hline Between groups & 7.87381282 & 16 & .492113301 & 11.71 & 0.0000 \\
within groups & 8.61527322 & 205 & .042025723 & & \\
Total & 16.489086 & 221 & .074611249 & & \\
\hline
\end{tabular}

Bartlett's test for equal variances: $\operatorname{chi} 2(16)=166.0989$ Prob $>$ chi $2=0.000$ 


\section{Appendix 5. One Way ANOVA for Board Size}

Table 5. Analysis of Variance

\begin{tabular}{llllll}
\hline Source & ss & df & MS & F & Prob $>$ F \\
\hline Between groups & 1073.24201 & 16 & 67.0776256 & 13.04 & 0.0000 \\
within groups & 1054.73997 & 205 & 5.14507304 & & \\
Total & 2127.98198 & 221 & 9.62887775 & & \\
\hline
\end{tabular}

Bartlett's test for equal variances: $\operatorname{chi} 2(7)=166.0989$ Prob $>$ chi2 $=0.000$

\section{Appendix 6. One-Way ANOVA for Proportion of Female Board members}

Table 6. Analysis of Variance

\begin{tabular}{llllll}
\hline Source & ss & df & MS & F & Prob $>$ F \\
\hline Between groups & .065708346 & 2 & .032854173 & 5.21 & 0.0097 \\
within groups & .258776683 & 41 & .006311626 & & \\
Total & .324485029 & 43 & .007546163 & & \\
\hline
\end{tabular}

Bartlett's test for equal variances: $\operatorname{chi} 2(1)=2.0992$ Prob $>$ chi $2=0.147$

\section{Appendix 7. One Way ANOVA for Proportion of Non-Executive Directors}

Table 7. Analysis of Variance

\begin{tabular}{llllll}
\hline Source & ss & df & MS & F & Prob $>$ F \\
\hline Between groups & .405082135 & 16 & .025317633 & 11.73 & 0.0000 \\
within groups & .442385966 & 205 & .00215798 & & \\
Total & .847468102 & 221 & .003834697 & & \\
\hline
\end{tabular}

Bartlett's test for equal variances: $\operatorname{chi} 2(5)=168.7888$ Prob $>\operatorname{chi} 2=0.000$

\section{Copyright Disclaimer}

Copyright for this article is retained by the author(s), with first publication rights granted to the journal.

This is an open-access article distributed under the terms and conditions of the Creative Commons Attribution license (http://creativecommons.org/licenses/by/3.0/). 